\title{
Comparative Effects of Different Disturbances in Coral Reef Habitats in Moorea, French Polynesia
}

\author{
Mélanie L. Trapon, ${ }^{1}$ Morgan S. Pratchett, ${ }^{1}$ and Lucie Penin ${ }^{1,2}$ \\ ${ }^{1}$ ARC Centre of Excellence for Coral Reef Studies, James Cook University, Townsville, QLD 4811, Australia \\ ${ }^{2}$ USR CNRS-EPHE 3278 CRIOBE Centre de Recherches Insulaires et Observatoire de l'Environnement, Université de Perpignan, \\ 66860 Perpignan Cedex, France
}

Correspondence should be addressed to Morgan S.Pratchett, morgan.pratchett@jcu.edu.au

Received 25 May 2010; Revised 16 August 2010; Accepted 10 September 2010

Academic Editor: Robert J. Toonen

Copyright (C) 2011 Mélanie L. Trapon et al. This is an open access article distributed under the Creative Commons Attribution License, which permits unrestricted use, distribution, and reproduction in any medium, provided the original work is properly cited.

Degradation and loss of critical coastal habitats has significant ramifications for marine fisheries, such that knowledge of changes in habitat quality and quantity are fundamental to effective ecosystem management. This study explores changes in the structure of coral reef habitats, specifically changes in coral cover and composition, in Moorea, French Polynesia, to assess the independent and combined effects of different disturbances since 1979. During this period, reefs on the north coast have been subject to coral bleaching, severe tropical storms, as well as outbreaks of Acanthaster. Coral cover varied significantly among years, showing marked declines during some, but not all, disturbances. The greatest rates of coral loss coincided with outbreaks of A. planci. Moreover, successive disturbances have had differential effects among coral genera, leading to strong directional shifts in coral composition. Acropora is declining in abundance and coral assemblages are becoming increasingly dominated by Pocillopora and Porites. Observed changes in the cover and composition of corals are likely to have further significant impacts on the reef fish assemblages. Given that significant disturbances have been mostly associated with outbreaks of $A$. planci, rather than climate change, effective ecosystem management may reduce and/or delay impending effects of climate change.

\section{Introduction}

Disturbances play an important role in the structure and dynamics of marine communities and are a necessary part of ecosystem dynamics [1-4]. On coral reefs, moderate levels of disturbance make an important contribution to increasing biodiversity [5]. In many locations, however, natural acute "pulse" disturbances have combined with chronic "press" [6] anthropogenic stresses (e.g., overfishing, pollution and eutrophication) to cause excessive disturbance and degradation of coral reef environments $[7,8]$. On a global scale, it is estimated that $30 \%$ of coral reefs have now lost $>90 \%$ of reef-building corals and there is little to no prospect of recovery [9]. Moreover, $60 \%$ of coral reefs around the world may face a similar fate by $2030[9,10]$. The loss of reef-building corals is likely to have major impacts on the biodiversity, productivity, and biological functioning of coral reef ecosystems $[11,12]$. In some locations, changes in the structure and quality of benthic reef habitats are now the most important driver of changes in the abundance of reef fishes (including some large piscivorous species), having a greater influence than extractive fisheries $[13,14]$.

Major contributors to coral loss and coral reef degradation vary regionally [15], but most reef areas are exposed to multiple disturbances [12]. Areas in which coral reef degradation is most pronounced (the Caribbean, SE Asia, and the western Indian Ocean) are characterized by a long history of heavy exploitation of coral reef resources and other chronic disturbances [9], which may have increased vulnerability to recent acute disturbances, such as severe tropical storms [16-20], El Niño Southern Oscillation (ENSO) events [21, 22], coral bleaching events [23-28], high and low temperature extremes, freshwater plumes from heavy rainfall and runoff events [29], coral diseases [30], and outbreaks of coral predators (mainly, the corallivorous sea star Acanthaster planci in the Indo-Pacific, [31-39], and 
tidal fluctuations [40]). More importantly, coral loss and associated degradation of coral reef habitats is expected to worsen over the next 2-3 decades, due to climate related increases in temperature [41] and ocean acidification [42].

Effects of acute disturbances on coral assemblages vary greatly, both within and among different types of disturbance. Disturbances that result in an immediate loss of habitat complexity (e.g., severe tropical storms) tend to have a greater impact on fishes from all trophic levels, compared with disturbances that kill corals, but do not immediately compromise the structure of reef habitats (e.g., coral bleaching and outbreaks of Acanthaster planci) [12]. Disturbances of a similar type (e.g., cyclones) may also differ in terms of the spatial scale of impact on habitat, intensity, magnitude, and duration of effect [5, 6]. Moreover, responses to disturbances will vary among locations, according to the history of disturbances that have already modified community structure [3], the stage of recovery since the last major disturbances [43-45], as well as inherent differences in community structure at large geographical scales [46]. Despite these differences, increases in the diversity, frequency, and intensity of disturbances in many reefs throughout the world tend to be causing clear directional changes in the structure of coral reef habitats $[8,47]$. In general, increasing disturbances cause declines in the abundance of habitat-forming corals, which may, in some situations, be replaced with macroalgae (e.g., [48]). Even if coral cover does not decline there may be marked changes in community structure of coral assemblages (e.g., [49]).

Effects of disturbances on coral composition depend on selectivity of effects, and differential vulnerabilities among major coral taxa (common families and genera). Acropora, for example, is the first and worst affected genera during coral bleaching [50,51], outbreaks of A. planci [52], and cyclones [20], whereas massive corals, such as Porites and Favia are resistant to all but the most severe disturbances. Consequently, erect branching corals (e.g., Acropora) are increasingly being replaced with encrusting and/or massive corals (e.g., Porites) at locations with extreme disturbance regimes (e.g., the Arabian Gulf; [53, 54]), which greatly reduced habitat availability and topographical complexity of coral reef environments. Acropora and other branching corals are the predominant habitat used by most coraldwelling fishes [55], while habitats with low complexity and topographic relief support far fewer fishes (e.g., $[13,38]$ ) owing to the critical role of topographic complexity in moderating recruitment, competition, and predation [56]. It is important therefore, to assess whether changes in the structure of coral assemblages observed in the Arabian Gulf, may ultimately occur at other locations the Indo-Pacific, especially given projected increases in the severity and/or frequency of disturbance [41].

A critical limitation in understanding effects of persistent or recurrent disturbances on coral reefs is the lack of long-term data [12]. Most studies are conducted at very limited temporal and spatial scales [57], and there are a limited number of locations around the world where there has been sufficient research conducted over an extended period to provide information on long-term changes in

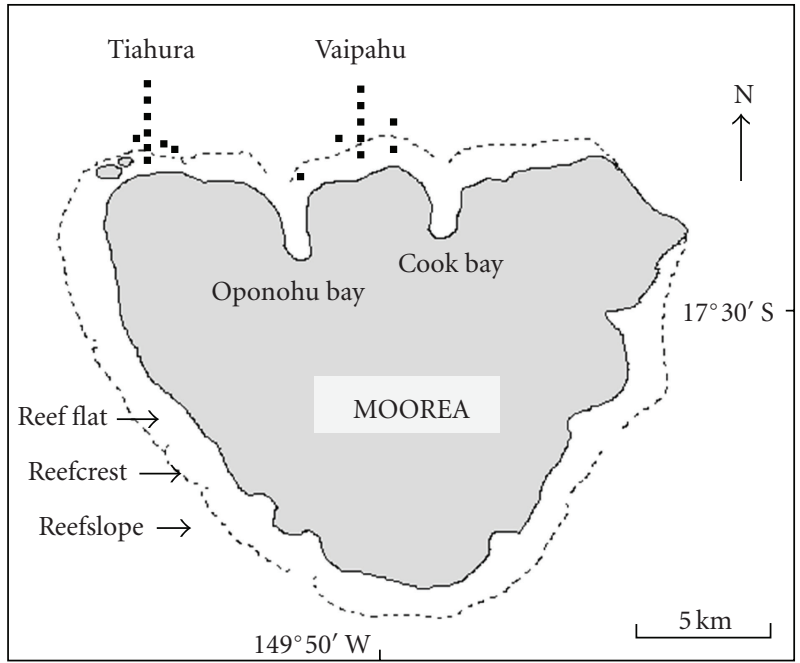

- Study sites

Figure 1: Map of Moorea $\left(17^{\circ} 30^{\prime} \mathrm{S}, 149^{\circ} 50^{\prime} \mathrm{W}\right)$ in the Society Island, French Polynesia, showing the main study sites on the reef flat, reef crest and reef slope at Tiahura (North-West) and Vaipahu (North-East). Dashed lines represent the approximate extent of the reef front.

coral composition associated with multiple and successive disturbances $[12,16,58]$. One of the major centers for coral reef research in the central Pacific is Moorea $\left(17^{\circ} 30^{\prime} \mathrm{S}, 149^{\circ} 50^{\prime} \mathrm{W}\right)$ in the Society Islands, French Polynesia (National Science Foundation Long-Term Ecological Research program-http://www.lternet.edu/sites/mcr/; Program "Agencement Temporel des Populations et des Peuplements", USR CNRS-EPHE3278 CRIOBE). Changes in coral cover and composition (mostly to genus) have been documented in Moorea since the 1970s by [59] and Bouchon [60], focusing on Tiahura reef on the northwest corner of Moorea (Figure 1). Since that time, extensive coral reef research and monitoring has been undertaken at Tiahura reef (and to a lesser extent at Vaipahu, situated approximately $12 \mathrm{~km}$ east of Tiahura, Figure 1). During this period, coral assemblages have been subject to many acute (pulse) disturbances, which are purported to have caused major changes in the community structure of coral reef communities [49]. Most notably, multispecific coral bleaching has been reported every 3-4 years since 1983 (1984, 1987, 1991, 1994, 2002, 2003, and 2007), corresponding with periods when sea surface temperature increased above $29.2^{\circ} \mathrm{C}[16,26,58,61]$. Then, cyclones have been reported to occur in Moorea during two El Nino events in 1983 and 1991, but in general are rare in French Polynesia (Table 1). Finally, two outbreaks of crown-of-thorn sea star occurred in Moorea, the first from 1979 to 1985 , and the second one which started in 2006 was still occurring in 2009 when the reef was resurveyed by Pratchett et al. (Table 1 ).

looseness=-1The purpose of this study was to assess the recent history of disturbances affecting coral reefs of Moorea, French Polynesia, based on extensive field-based research undertaken at this location since 1979. In addition 
to documenting the occurrence of distinct disturbance events, changes in cover and composition of reef-building corals were assessed following each major disturbance event. These data provide insights into the comparative effects of different disturbances, as well as revealing long-term effects of recurrent disturbances on coral reefs in the central Pacific. Assessing the major causes of coral loss is particularly important in establishing potential management strategies to address habitat-degradation (specifically, declines in habitat diversity and structural complexity) within ecosystem management frameworks.

\section{Materials and Methods}

To explore long-term changes in coral cover and community structure at Moorea, quantitative data were compiled from 15 studies conducted at Tiahura [16, 33, 49, 58, 62-70] and/ or Vaipahu [16, 62, 71, 72], located 2 kilometres apart on the north coast of Moorea [62]. Most of these studies (11 studies) directly compared changes in coral cover and composition through time, sampling coral assemblages between 2-17 years. This study also encompasses data from two previous studies, that document long-term changes in coral cover and composition $[49,58]$. However, this study extends the temporal and spatial extent of these data sets. Most importantly, it includes knowledge of recent changes in coral cover and composition, from 2006-2009, during which time there was a major outbreak of $A$. planci.

To account for differences in sampling among specific habitats or depths, we pooled data across different reef zones (up to 7) to distinguish between: (i) shallow habitats (from 0 to $5 \mathrm{~m}$ ), which encompass the barrier reef flat, the barrier reef crest, and the upper part of the outer-reef slope and (ii) deep habitats ( 10 to $30 \mathrm{~m}$ ), encompassing the outer-reef slope. We calculated a mean coral cover for each of these habitats, at each site, and in each year. Whenever possible, we also considered the structure of coral communities, based on relative abundance of the major coral genera Pocillopora, Acropora, Montipora, and Porites. All other corals were then lumped into a single category, "others".

The temporal occurrence and severity of major disturbances such as coral bleaching events, cyclones, and outbreaks of Acanthaster planci (A. planci) was assessed based on a comprehensive review of published literature (Table 1). To relate changes in total coral cover to the occurrence of disturbances, we calculated annual geometric rate of change in total coral cover for each year, following Côté et al. [73]. Geometric rates of change in live coral cover are calculated based on the relative change in coral cover between respective samples, without assuming a linear decline in coral cover, which is necessary when comparing among different sampling intervals. The average annual rate of change was then compared among individual years in which different types of disturbances (bleaching, cyclones, and outbreaks of $A$. planci) occurred. It was not possible to partition effects of different disturbances that occurred simultaneously, though there were only three years (1983, 1991, and 2007), where multiple disturbances occurred within the same year. Unfortunately, however, both cyclones occurred in years with either bleaching (1991) or bleaching and outbreaks of $A$. planci (1983), making it difficult to assess the independent effect of these disturbances.

\section{Results and Discussion}

3.1. Episodic Disturbances and Changes in Coral Cover. Since 1979, Moorea has been subject to seven coral bleaching events, two cyclones and two major outbreaks of Acanthaster planci (Table 1). As such, coral assemblages have been subject to an average of one disturbance every 2.7 years. Coral cover has varied considerably throughout this period, starting with mean cover of $40.9 \%( \pm 4.9 \mathrm{SE})$ in 1979 , and ending with $16.5 \%( \pm 5.9 \mathrm{SE})$ in 2009. Coral cover recorded in 2009 (especially on the reef slope) was the lowest that has been recorded since 1979. However, coral cover has not exhibited a systematic decline through time, rather live coral increased to $>50 \%$ on outer reef slopes in 1991, and also in 2004, immediately prior to the most recent outbreak of $A$. planci (Figures 2 and 3). Although there is limited data on chronic disturbances affecting the study locations in Moorea (e.g., fishing pressure, sedimentation, and/or eutrophication), it appears that periodic depletion of live corals is largely explained by the occurrence of acute disturbances (Figures 2 and 3), including bleaching, cyclones, and outbreaks of A. planci, all of which have contributed to significant coral depletion elsewhere throughout the Pacific $[7,12]$.

The average annual rate of change in coral cover recorded in years during which acute disturbances were reported was $-25.6( \pm 11.6 \mathrm{SE})$, compared to $1.5( \pm 1.8 \mathrm{SE})$ in years with no reported disturbances. Average rates of coral loss were significantly different among years in which bleaching was reported to occur, versus cyclones or outbreaks of $A$. planci (ANOVA, $F=9.38, d f=3 / 96, P<.001$ ). Among the different types of disturbances, overall rates of coral loss (averaged across zones and locations) were greatest (mean $=-33.2 \pm 14.1 \mathrm{SE}$ ) during outbreaks of A. planci, and significantly higher than rates of coral loss recorded during bleaching events (Tukeys Post-Hoc, $J=0.41, P=$ .003). The two major cyclones affecting Moorea (in 1983 and 1991) were associated very high rates of coral loss, but these disturbances coincided outbreaks of $A$. planci and/or bleaching (Figures 2(a) and 2(b)), making it difficult to assess the individual contribution of cyclones to recorded coral loss. However, the average rate of coral loss across years with multiple disturbances was higher than for recorded during any single disturbance, suggesting that different disturbances may have additive effects on coral loss (Figure 4).

During the course of the study (1979-2009), there were two distinct outbreaks of A. planci. The first of these outbreaks began in 1979, with infestations of sea stars first observed on the deep reef slope at Tiahura reef [68]. This initial infestation seemed to have ended by 1986 at Tiahura reef [68], but there were significant ongoing outbreaks in southern parts of Moorea until 1987 [33], probably reflecting the movement of sea stars as well as increased settlement of larval sea stars spawned by infestations of reproductively 


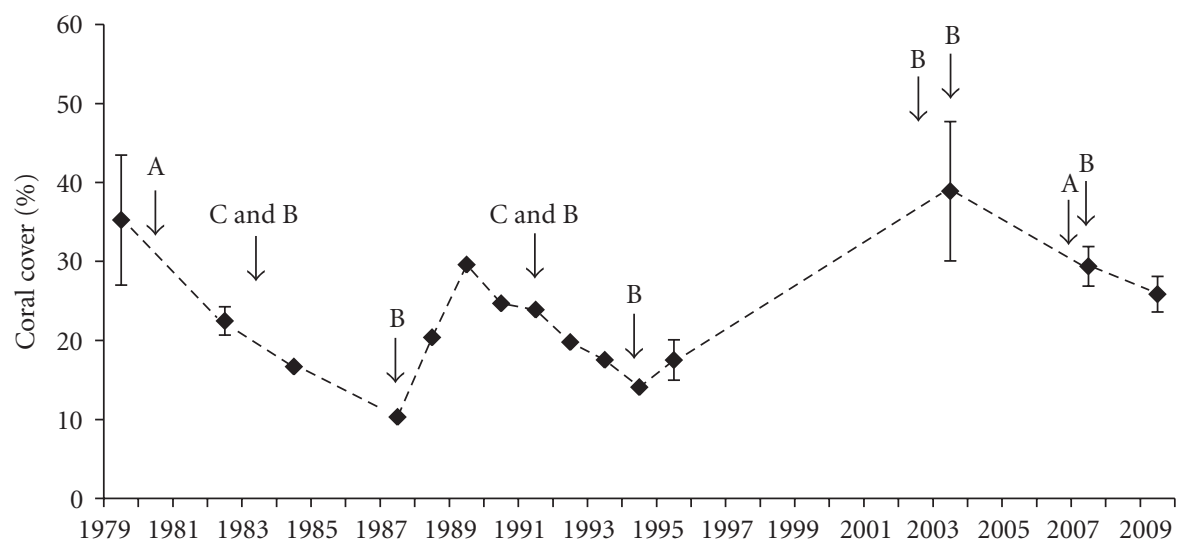

(a) Tiahura $(0-5 \mathrm{~m})$

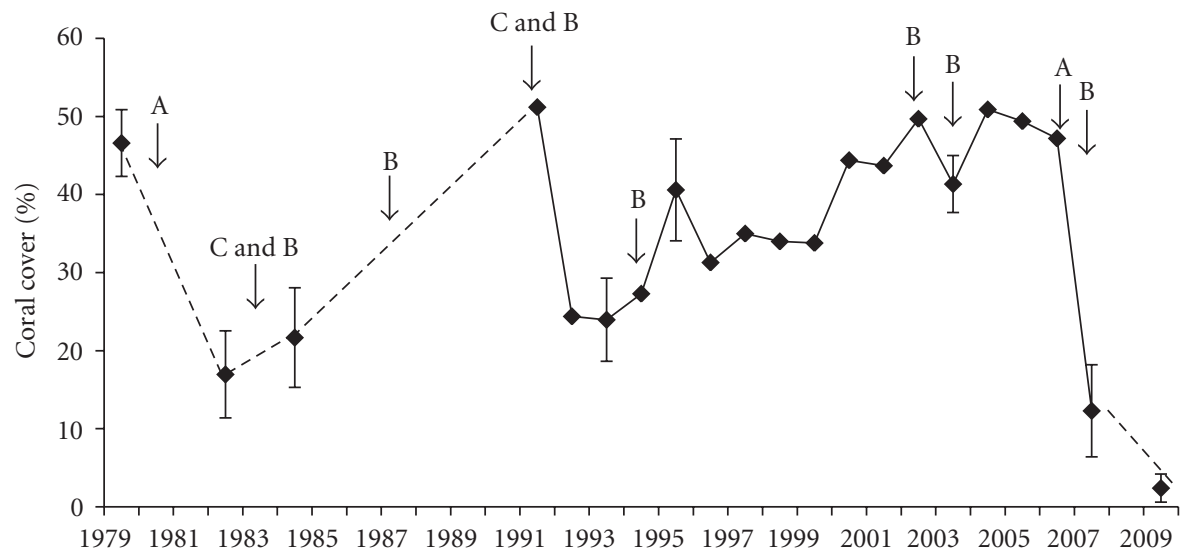

(b) Tiahura $(10-30 \mathrm{~m})$

FIGURE 2: Interannual variation in mean $( \pm \mathrm{SE})$ coral cover in (a) shallow habitats $(0-5 \mathrm{~m})$, and $(\mathrm{b})$ deep habitat $(0-30 \mathrm{~m})$, and at the Tiahura reef, Moorea. Dashed lines indicate presumed trend across years for which no survey data are available. The occurrence of outbreaks of $A$. planci (A), coral bleaching (B), and cyclones (C) is shown.

mature sea stars in northern Moorea, as reported by Pratchett [36] at Lizard Island on the northern Great Barrier Reef. The most recent and only second known outbreak of $A$. planci in Moorea started in 2006 [58], with high densities of sea stars again being recorded first on the outer-reef slope of Tiahura $\left(23,000\right.$ sea stars $\mathrm{km}^{-2}$, according to Lison de Loma et al. [74]) which was far higher than the density threshold of $>1500$ sea stars $\mathrm{km}^{-2}$, considered to cause devastation to reef habitats by Moran and De'ath [75]. Accordingly, rates of coral loss recorded during outbreaks of $A$. planci were much higher on the reef slope, compared to the reef flat (Figure 4), which is consistent with observations of $A$. planci impacts elsewhere in the world (reviewed by Moran [76]).

Outbreaks of $A$. planci are one of the most significant biological disturbances on coral reefs [77] and remain the principal cause of short-term coral loss in the Indo-Pacific [15], often killing up to $90 \%$ of scleractinian corals, for example, on the Great Barrier Reef [36, 78, 79], in Guam [80], in Papua New Guinea [81] and in Japan [39]. After the first outbreak of $A$. planci in Moorea (1979-1986), coral cover at Tiahura increased rapidly and returned to predisturbance levels $(46.6 \%)$ within less than 5 years. In other geographic locations, recovery of coral cover following outbreaks of $A$. planci has typically taken much longer (e.g., Great Barrier Reef-10 to 15 years, [82]; 10 to 20 years, [83]; 10 to 25 years, [84] and 20 to 40 years, [32]; Guam-11 years, [85]; 20 to 30 years, [86]). Coral recovery was even more pronounced in deep water where the coral cover increased from $<20 \%$ in 1982 to $51 \%$ in 1991 (Figure $2(\mathrm{a})$ ). This apparent resilience in coral cover on reefs in Moorea has been reported previously and may be attributable to consistently high rates of coral recruitment [58]. However, relatively rapid increase in total coral cover may belie fundamental changes in coral composition [49] and thereby habitat structure. Moreover, the amount of remnant corals on the reef slope in 2009 was much lower compared to the end of the first A. planci outbreak in 1982 (Figure 2), which may suggest that recovery from the latest outbreak of $A$. planci will take substantially longer [87].

Coral bleaching has occurred every 3-4 years at Moorea since 1983, but these mass-bleaching events have not caused consistent declines in live coral cover. The greatest rates of coral change recorded during bleaching years (1991 and 2007 ) both coincide with other disturbances (a cyclone and outbreak of $A$. planci, resp.), whereas in all other years that bleaching has been recorded, coral loss was negligible. Coral 


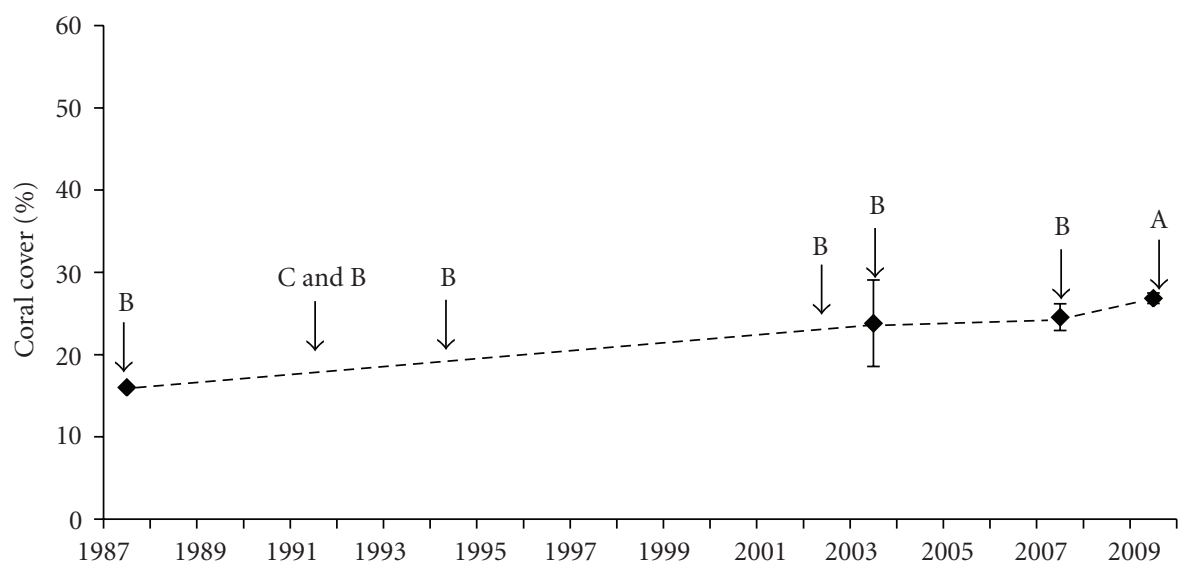

(a) Viapahu $(0-5 \mathrm{~m})$

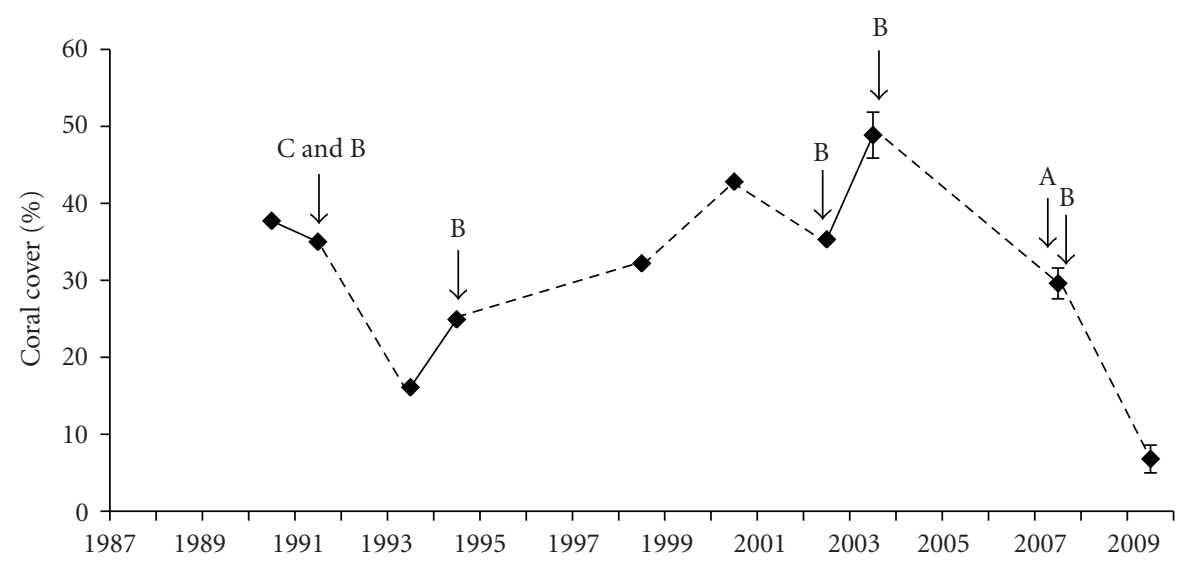

(b) Viapahu (10-30 m)

Figure 3: Interannual variation in mean $( \pm \mathrm{SE})$ coral cover in (a) deep habitat $(0-30 \mathrm{~m})$ and (b) shallow habitats $(0-5 \mathrm{~m})$ at the Viapahu reef, Moorea. Dashed lines indicate presumed trend across years for which no survey data is available. The occurrence of outbreaks of $A$. planci (A), coral bleaching (B), and cyclones (C) is shown.

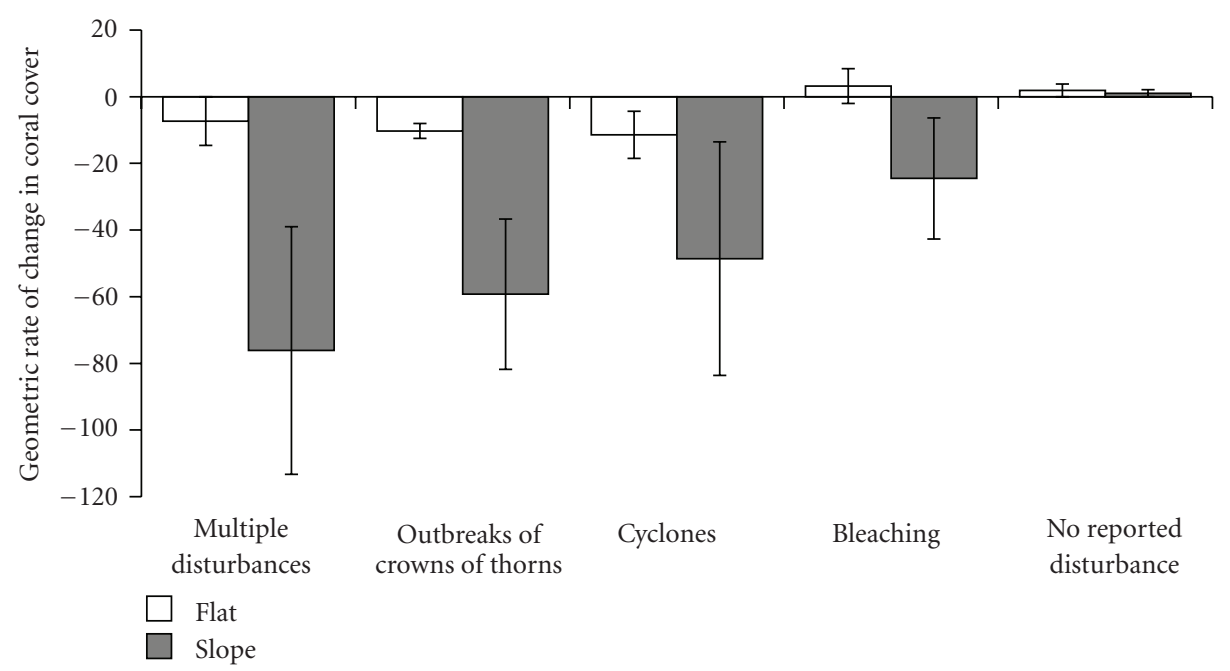

FIGURE 4: Variation in the mean $( \pm$ SE) annual geometric rate of change in total cover of scleractinian corals, for years (between 1979 and 2008) during which outbreaks of A. planci (1979-1986, 2006-2008), cyclones (1983 and 1991), or bleaching (1983, 1987, 1991, 1994, 2002, 2003, and 2007) were reported. 
TABLE 1: Episodic disturbances that have affected Moorea Island, and geometric rate of change in mean coral cover ( $\Delta$ Coral cover) reported to occur between successive surveys spanning each disturbance.

\begin{tabular}{|c|c|c|c|}
\hline Disturbances & Period & Reference(s) & $\Delta$ Coral cover \\
\hline \multirow{7}{*}{ Bleaching Events } & March-May, 1983 & $\begin{array}{l}\text { Williams and Bunkley-Williams [28], } \\
\text { Glynn [22], Salvat [88] }\end{array}$ & $-2.2( \pm 13.8 \mathrm{SE})$ \\
\hline & March-April, 1987 & $\begin{array}{l}\text { Williams and Bunkley-Williams [28], } \\
\text { Glynn [22], Salvat [88] }\end{array}$ & $21.1( \pm 14.4 \mathrm{SE})$ \\
\hline & March-April, 1991 & $\begin{array}{l}\text { Salvat [88], Gleason [72], Adjeroud et al. } \\
{[58]}\end{array}$ & $-43.9( \pm 24.2 \mathrm{SE})$ \\
\hline & February-April, 1994 & $\begin{array}{l}\text { Hoegh-Guldberg and Salvat }[26] \\
\text { Adjeroud et al. }[16,58]\end{array}$ & $15.3( \pm 6.9 \mathrm{SE})$ \\
\hline & April-July, 2002 & Adjeroud et al. $[16,58]$, Penin et al. [61] & $4.9( \pm 9.9 \mathrm{SE})$ \\
\hline & January-March, 2003 & Carroll et al. (unpulished data) & $-0.3( \pm 13.9 \mathrm{SE})$ \\
\hline & February-April 2007 & $\begin{array}{l}\text { Adjeroud et al. [58], Pratchett et al. [62], } \\
\text { Penin et al. (unpublished data) }\end{array}$ & $-59.3( \pm 4.0 \mathrm{SE})$ \\
\hline \multirow{2}{*}{ Cyclones } & April, 1983 & Harmelin-Vivien and Laboute [19] & $-2.2( \pm 13.8 \mathrm{SE})$ \\
\hline & December, 1991 & Gleason $[72]$ & $43.9( \pm 24.2 \mathrm{SE})$ \\
\hline \multirow{2}{*}{$\begin{array}{l}\text { Acanthaster planci } \\
\text { outbreaks }\end{array}$} & 1979-1986 & Bouchon [60], Faure [33] & $-12.2( \pm 4.5 \mathrm{SE})$ \\
\hline & $2006-2009$ & $\begin{array}{l}\text { Lison de Loma et al. [74], Pratchett et al. } \\
\text { [62] }\end{array}$ & $-64.8( \pm 25.4 \mathrm{SE})$ \\
\hline
\end{tabular}

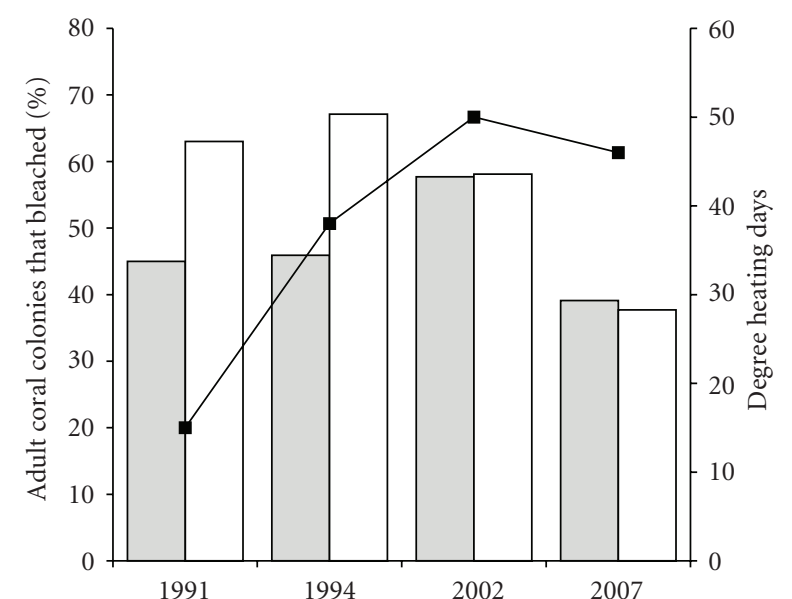

Figure 5: Percentage of adult coral colonies that bleached at Tiahura (grey bars) and Viaphu (white bars), versus the duration of temperature anomalies (degree heating days) during four episodes of mass-bleaching in Moorea. Degree heating days were calculated for the summer period (September-March) in each year that massbleaching was documented (generally between February and April), based on $4 \mathrm{~km}$ Pathfinder (NOAA) data for Tiahura Reef with backfilling and smoothing functions to eliminate null values.

bleaching generally occurs at Moorea whenever sea surface temperature (SST) exceeds the notional threshold of $29.2^{\circ} \mathrm{C}$ for more than several weeks $[16,26,58,61,64]$. There does not, however, seem to be any significant relationship between the extent of bleaching recorded during major mass-bleaching events (1991, 1994, 2002, and 2007) and the temporal duration of thermal anomalies (Figure 5). On the outer-reef slope at Tiahura and Vaipahu, the percentage of coral that bleached in 1991 was $45 \%$ and $63 \%$, respectively, [72, 88], compared to $45.9 \%$ and $67.1 \%$ in 1994 [26], $57.7 \%$ and $58.1 \%$ in 2002 [61], and $39.1 \%$ and $37.7 \%$ in 2007 (Penin et al. unpublished data). As such, the severity of bleaching appears to have declined, even though the severity of temperature extremes (degree heating days) has increased among these bleaching events (Figure 5). Declines in the response of corals, despite similar or worsening thermal stresses, suggest that corals and/or the zooxanthellae may have acclimatized or adapted to increasing temperature, and may therefore, be less susceptible to future thermal anomalies $[89,90]$. Alternatively, successive disturbances are likely to cause changes in the structure of coral assemblages, increasing the proportional abundance of species and genotypes that are most resistant to bleaching $[25,91]$. If the latter is true, then severe bleaching and high rates of coral mortality may result with further increases in the severity and/or duration of temperature stresses.

3.2. Persistent Shifts in Coral Composition. Aside from causing marked changes in live cover, acute disturbances occurring in Moorea from 1979 to 2009 have caused significant and persistent shifts in coral composition (Figures 4(a) and 4(b)). In 1979, coral communities at Tiahura were mostly dominated by Acropora (Figures 4(a) and 4(b)). However, the A. planci outbreaks in late 1970s greatly affected Acropora corals which declined by $84.3 \%$ throughout the reef by 1982 . While coral cover increased rapidly following the initial outbreak of A. planci, the postoutbreak coral composition was very different compared to the composition recorded in 1979 [60]. Berumen and Pratchett [49] described apparent recovery of coral cover despite marked temporal changes in coral composition as evidence that recurrent disturbances were causing a pronounced shifts in the structure of local coral assemblages. In 2003, Pocillopora was the most abundant genus in Moorea (Figures 4(a) and 4(b)), probably because it is less affected by coral bleaching, outbreaks 


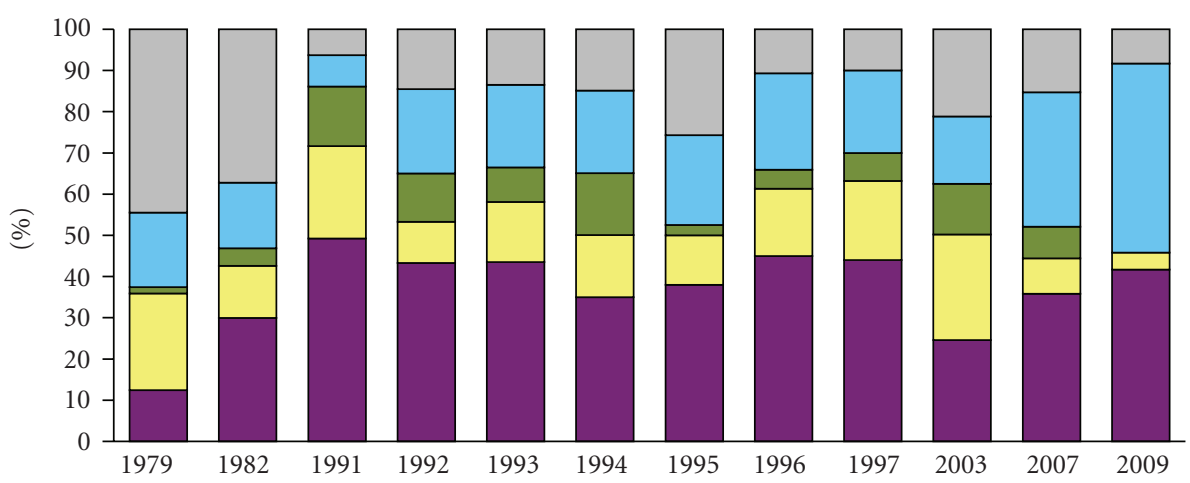

(a) Deep habitat $(10-30 \mathrm{~m})$

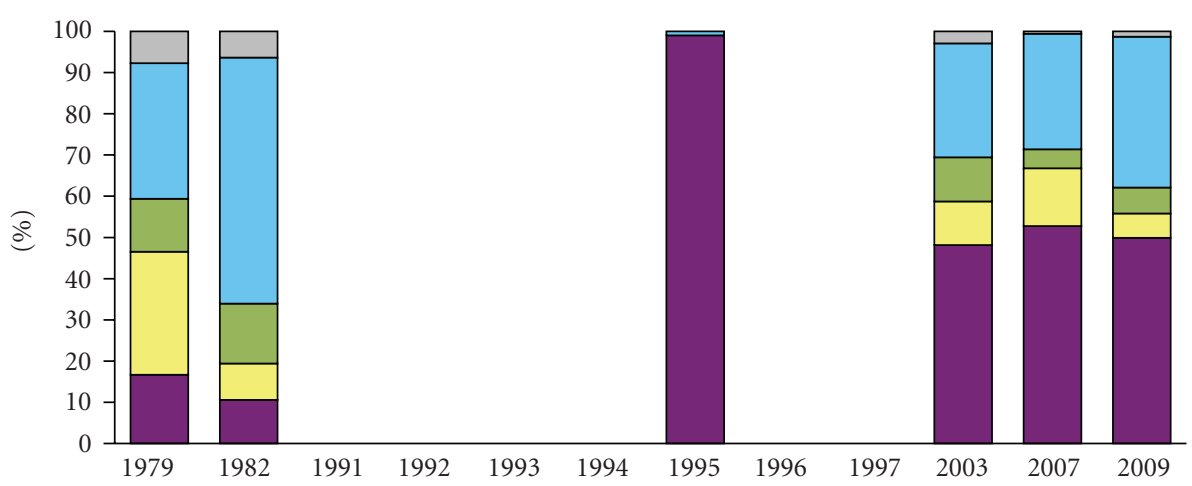

(b) Shallowhabitat $(0-5 \mathrm{~m})$

FIGURE 6: Interannual variation in relative abundance of major coral genera at Tiahura reef, Moorea Island.

of A. planci [92, 93], and tropical storms [49], especially compared to Acropora corals. Pocillopora corals increased in their relative abundance after the initial outbreak accounting for $30 \%$ and $49.2 \%$ of the coral cover on the reef slope (10 to $20 \mathrm{~m}$ ) in 1982 and 1991, respectively, and remained the dominant coral until 2009 (Figure 4(a)). Similarly, in shallow waters habitats, the dominant coral genera changed from Acropora to Porites after the first outbreak of A. planci in 1982 (Figure 4(b)).

Acanthaster planci selectively feed on certain coral species, mostly Acropora [93, 94]. Accordingly, the proportional cover of Acropora (relative to all other genera) declined from $(26.5 \%)$ in 1979 , before the first reported outbreak of A. planci, down to $11.0 \%$ in 1982 (Figure 4). Further changes in coral composition were apparent in 1991, whereby the prevalence of Acropora coral was further diminished, probably due to their disproportionate susceptibility to both coral bleaching and storm damage [72]. Both Pocillopora and Porites have tended to increase in prevalence through time at the expense of Acropora corals and other coral genera (Figure 4). The most recent outbreak of $A$. planci (2006-2009) has further reduced proportional and absolute abundance of Acropora corals which accounted for only $4.2 \%$ of the coral cover in deep habitat and 5.9\% in shallow habitat in 2009 (Figure 4, [62]). In contrast, Porites and Pocillopora corals accounted for $45.8 \%$ and $41.7 \%$ of the coral cover in deep habitat, respectively, and $36.6 \%$ and $49.9 \%$ in shallow habitat in 2009. Despite an increase in proportional cover of
Porites and Pocillopora corals, absolute cover of these genera has also declined during the latest outbreak of $A$. planci. This is consistent with observed feeding habitats of $A$. planci whereby starfishes will tend to consume more of their less preferred prey corals when the overall abundance of the preferred prey drops [94].

Although not measured in Moorea, declines in the abundance of branching corals, especially Acropora and Pocillopora, are likely to cause reductions in diversity and topographical complexity of coral reef habitats [95]. This will, in turn, affect many other reef-associated species [13, 96]. Acropora and other branching corals are the predominant habitat used by coral-feeding and coral-dwelling species, and specialized species may disappear following declines in abundance of these microhabitats [96, 97]. Moreover, any declines in habitat diversity and complexity are likely to reduce the number of species that cooccur in coral reef habitats $[13,38]$, owing to the role of topographic complexity in moderating competition and predation [56]. In Moorea, these effects may be partly offset, by increases in the abundance of Pocillopora (Figure 6). However, declines in abundance of Acropora from 1979 to 2003 have already caused significant declines in the abundance of (coralfeeding) butterflyfishes that specialize on Acropora [49], and these fishes ( $C$. reticulatus and $C$. trifascialis) may now be facing localized extinction (especially on the reef slope) given further declines in abundance of both Acropora, as well as other potential coral prey. 


\section{Conclusion and Management Implications}

Coral reefs on the north coast of Moorea have been subject to several periods of extensive coral loss since 1979, caused by outbreaks of $A$. planci, cyclones, and/or bleaching. The greatest rates of coral loss recorded occurred during two major outbreaks of A. planci in 1979-1982 and 2006-2009, which caused particularly severe coral loss on the outer-reef slope. Moreover, coral loss was greatest among Acropora corals, thereby contributing to a marked shift in the composition of coral assemblages. Until now, effects of coral bleaching on local coral cover appear to have been fairly minor, especially compared to outbreaks of A. planci. However, projected increases in ocean temperatures, as well as ocean acidification, may yet cause significant coral loss in Moorea, and throughout the Pacific [98]. Hoegh-Guldberg et al. [98] predict that average coral cover on reefs in the Pacific will decline by $30 \%-40 \%$ in the coming decades, due to increasing effects of global climate change. Moreover, robust species such as Porites and Favia are expected to replace branching species, mostly Acropora, as the dominant coral genera [98].

Coral reef ecosystems are fundamental to coastal fisheries, and the provision of fresh seafood, throughout the Pacific. However, increasing disturbances, and the associated degradation of coral reef habitats threaten to undermine the capacity of these ecosystems to yield sufficient food and resources [99]. Climate change will, therefore, represent a major challenge for Pacific countries in the coming decades. However, in locations where major cause(s) of coral loss relate to more direct anthropogenic disturbances (e.g., fishing and eutrophication), improved local management may serve to reduce and/or delay effects of climate change. There is considerable controversy relating to the role of anthropogenic activities in causing and/or exacerbating outbreaks of A. planci. However, on the Great Barrier Reef, it is suggested that outbreaks result from increased nutrient loads [100] and/or overfishing of predatory fishes [101, 102]. There is a potential, therefore, that reduced fishing and/or improved water quality will minimize the occurrence and impacts of outbreaks of A. planci. In this instance, ecosystem management may provide an effective strategy to reduce a major contributor to coral loss in Moorea, and thereby improve ecosystem resilience to future climate change.

\section{Acknowledgments}

This study was funded by the ARC Centre of Excellence for Coral Reef Studies and made possible through extensive knowledge on the Moorea reef past history from staff at CRIOBE (USR CNRS-EPHE 3278), Moorea.

\section{References}

[1] J. H. Connell, "Disturbance and recovery of coral assemblages," Coral Reefs, vol. 16, no. 1, pp. S101-S113, 1997.

[2] A. Halford, A. J. Cheal, D. Ryan, and D. M. Williams, "Resilience to large-scale disturbance in coral and fish assemblages on the great barrier reef," Ecology, vol. 85, no. 7, pp. 1892-1905, 2004.
[3] T. P. Hughes and J. H. Connell, "Multiple stressors on coral reefs: a long-term perspective," Limnology and Oceanography, vol. 44, no. 3, pp. 932-940, 1999.

[4] R. H. Karlson and L. E. Hurd, "Disturbance, coral reef communities, and changing ecological paradigms," Coral Reefs, vol. 12, no. 3-4, pp. 117-126, 1993.

[5] J. H. Connell, "Diversity in tropical rain forests and coral reefs. High diversity of trees and corals is maintained only in a nonequilibrium state," Science, vol. 199, no. 4335, pp. 1302-1310, 1978.

[6] E. A. Bender, T. J. Case, and M. E. Gilpin, "Perturbation experiments in community ecology: theory and practice," Ecology, vol. 65, no. 1, pp. 1-13, 1984.

[7] D. R. Bellwood, T. P. Hughes, C. Folke, and M. Nyström, "Confronting the coral reef crisis," Nature, vol. 429, no. 6994, pp. 827-833, 2004.

[8] T. P. Hughes, A. H. Baird, D. R. Bellwood et al., "Climate change, human impacts, and the resilience of coral reefs," Science, vol. 301, no. 5635, pp. 929-933, 2003.

[9] C. R. Wilkinson, Status of Coral Reefs of the World: 2004, Australian Institute of Marine Science, Townsville, Australia, 2004.

[10] O. Hoegh-Guldberg, "Climate change, coral bleaching and the future of the world's coral reefs," Marine and Freshwater Research, vol. 50, no. 8, pp. 839-866, 1999.

[11] M. S. Pratchett and M. L. Berumen, "Interspecific variation in distributions and diets of coral reef butterflyfishes (Teleostei: Chaetodontidae)," Journal of Fish Biology, vol. 73, no. 7, pp. 1730-1747, 2008.

[12] S. K. Wilson, N. A. J. Graham, M. S. Pratchett, G. P. Jones, and N. V. C. Polunin, "Multiple disturbances and the global degradation of coral reefs: are reef fishes at risk or resilient?" Global Change Biology, vol. 12, no. 11, pp. 2220-2234, 2006.

[13] N. A. J. Graham, S. K. Wilson, S. Jennings, N. V. C. Polunin, J. P. Bijoux, and J. Robinson, "Dynamic fragility of oceanic coral reef ecosystems," Proceedings of the National Academy of Sciences of the United States of America, vol. 103, no. 22, pp. 8425-8429, 2006.

[14] S. K. Wilson, A. M. Dolman, A. J. Cheal, M. J. Emslie, M. S. Pratchett, and H. P. A. Sweatman, "Maintenance of fish diversity on disturbed coral reefs," Coral Reefs, vol. 28, no. 1, pp. 3-14, 2009.

[15] J. F. Bruno and E. R. Selig, "Regional decline of coral cover in the Indo-Pacific: timing, extent, and subregional comparisons," PLoS ONE, vol. 2, no. 8, article no. e711, 2007.

[16] M. Adjeroud, Y. Chancerelle, M. Schrimm et al., "Detecting the effects of natural disturbances on coral assemblages in French Polynesia: a decade survey at multiple scales," Aquatic Living Resources, vol. 18, no. 2, pp. 111-123, 2005.

[17] T. A. Gardner, I. M. Côté, J. A. Gill, A. Grant, and A. R. Watkinson, "Hurricanes and caribbean coral reefs: impacts, recovery patterns, and role in long-term decline," Ecology, vol. 86, no. 1, pp. 174-184, 2005.

[18] M. Harmelin-Vivien, "The effects of storms and cyclones on coral reefs: a review," Journal of Coastal Research, vol. 12, pp. 211-231, 1994.

[19] M. L. Harmelin-Vivien and P. Laboute, "Catastrophic impact of hurricanes on atoll outer reef slopes in the Tuamotu (French Polynesia)," Coral Reefs, vol. 5, no. 2, pp. 55-62, 1986.

[20] J. D. Woodley, E. A. Chornesky, P. A. Clifford et al., "Hurricane Allen's impact on Jamaican coral reefs," Science, vol. 214 , no. 4522, pp. 749-755, 1981. 
[21] P. W. Glynn, "Widespread coral mortality and the 1982-1983 El Niño warming event," Environmental Conservation, vol. 11, no. 2, pp. 133-146, 1984.

[22] P. W. Glynn, "Coral reef bleaching in the 1980s and possible connections with global warming," Trends in Ecology and Evolution, vol. 6, no. 6, pp. 175-179, 1991.

[23] A. C. Baker, P. W. Glynn, and B. Riegl, "Climate change and coral reef bleaching: an ecological assessment of longterm impacts, recovery trends and future outlook," Estuarine, Coastal and Shelf Science, vol. 80, no. 4, pp. 435-471, 2008.

[24] B. E. Brown, "Coral bleaching: causes and consequences," Coral Reefs, vol. 16, no. 1, pp. S129-S138, 1997.

[25] P. W. Glynn, "Coral reef bleaching: facts, hypotheses and implications," Global Change Biology, vol. 2, no. 6, pp. 495 509, 1996.

[26] O. Hoegh Guldberg and B. Salvat, "Periodic mass-bleaching and elevated sea temperatures: bleaching of outer reef slope communities in Moorea, French Polynesia," Marine Ecology Progress Series, vol. 121, no. 1-3, pp. 181-190, 1995.

[27] C. Wilkinson, "The 1997-1998 mass bleaching event around the World," AIMS Research, p. 23, 1998.

[28] E. H. Williams Jr. and L. Bunkley-Williams, "The worldwide coral reef bleaching cycle and related sources of coral mortality," Atoll Research Bulletin, vol. 335, pp. 1-71, 1990.

[29] M. McCulloch, S. Fallon, T. Wyndham, E. Hendy, J. Lough, and D. Barnes, "Coral record of increased sediment flux to the inner Great Barrier Reef since European settlement," Nature, vol. 421, no. 6924, pp. 727-730, 2003.

[30] E. P. Green and A. W. Bruckner, "The significance of coral disease epizootiology for coral reef conservation," Biological Conservation, vol. 96, no. 3, pp. 347-361, 2000.

[31] C. Birkeland, "Terrestrial runoff as a cause of outbreaks of Acanthaster planci (Echinodermata: Asteroidea)," Marine Biology, vol. 69, no. 2, pp. 175-185, 1982.

[32] R. Endean and R. H. Chesher, "Temporal and spatial distribution of Acanthaster planci population explosions in the Indo-West Pacific region," Biological Conservation, vol. 5, no. 2, pp. 87-95, 1973.

[33] G. Faure, "Degradation of coral reefs at Moorea Island (French Polynesia) by Acanthaster planci," Journal of Coastal Research, vol. 5, no. 2, pp. 295-305, 1989.

[34] P. J. Moran, R. H. Bradbury, and R. E. Reichelt, "Distribution of recent outbreaks of the crown-of-thorns starfish (Acanthaster planci) along the Great Barrier Reef: 1985-1986," Coral Reefs, vol. 7, no. 3, pp. 125-137, 1988.

[35] P. J. Moran, R. E. Reichelt, and R. H. Bradbury, "An assessment of the geological evidence for previous Acanthaster outbreaks," Coral Reefs, vol. 4, no. 4, pp. 235-238, 1986.

[36] M. S. Pratchett, "Dynamics of an outbreak population of Acanthaster planci at Lizard Island, northern Great Barrier Reef (1995-1999)," Coral Reefs, vol. 24, no. 3, pp. 453-462, 2005.

[37] R. E. Reichelt, R. H. Bradbury, and P. J. Moran, "Distribution of Acanthaster planci outbreaks on the Great Barrier Reef between 1966 and 1989," Coral Reefs, vol. 9, no. 3, pp. 97$103,1990$.

[38] M. Sano, M. Shimizu, and Y. Nose, "Long-term effects of destruction of hermatypic corals by Acanthaster planci infestation on reef fish communities at Iriomote Island, Japan," Marine Ecologie Progress Series, vol. 37, pp. 191-199, 1987.

[39] M. Yamaguchi, "Acanthaster planci infestations of reefs and coral assemblages in Japan: a retrospective analysis of control efforts," Coral Reefs, vol. 5, no. 1, pp. 23-30, 1986.
[40] Y. H. Fadlallah, K. W. Allen, and R. A. Estudillo, "Mortality of shallow reef corals in the western Arabian Gulf following aerial exposure in winter," Coral Reefs, vol. 14, no. 2, pp. 99107, 1995.

[41] S. D. Donner, "Coping with commitment: projected thermal stress on coral reefs under different future scenarios," PLoS ONE, vol. 4, no. 6, article no. e5712, Article ID e5712, 2009.

[42] O. Hoegh-Guldberg, P. J. Mumby, A. J. Hooten et al., "Coral reefs under rapid climate change and ocean acidification," Science, vol. 318, no. 5857, pp. 1737-1742, 2007.

[43] P. K. Dayton, M. J. Tegner, P. B. Edwards, and K. L. Riser, "Temporal and spatial scales of kelp demography: the role of oceanographic climate," Ecological Monographs, vol. 69, no. 2, pp. 219-250, 1999.

[44] T. P. Hughes, "Community structure and diversity of coral reefs: the role of history," Ecology, vol. 70, no. 1, pp. 275-279, 1989.

[45] J. B. C. Jackson, M. X. Kirby, W. H. Berger et al., "Historical overfishing and the recent collapse of coastal ecosystems," Science, vol. 293, no. 5530, pp. 629-637, 2001.

[46] D. R. Bellwood and T. P. Hughes, "Regional-scale assembly rules and biodiversity of coral reefs," Science, vol. 292, no. 5521, pp. 1532-1534, 2001.

[47] T. McClanahan, N. Polunin, and T. Done, "Ecological states and the resilience of coral reefs," Conservation Ecology, vol. 6, no. 2, article no. 18, 2002.

[48] T. P. Hughes, "Catastrophes, phase shifts, and large-scale degradation of a Caribbean coral reef," Science, vol. 265, no. 5178, pp. 1547-1551, 1994.

[49] M. L. Berumen and M. S. Pratchett, "Recovery without resilience: persistent disturbance and long-term shifts in the structure of fish and coral communities at Tiahura Reef, Moorea," Coral Reefs, vol. 25, no. 4, pp. 647-653, 2006.

[50] Y. Loya, K. Sakai, K. Yamazato, Y. Nakano, H. Sambali, and R. Van Woesik, "Coral bleaching: the winners and the losers," Ecology Letters, vol. 4, no. 2, pp. 122-131, 2001.

[51] T. R. McClanahan, M. Ateweberhan, N. A. J. Graham et al., "Western Indian Ocean coral communities: bleaching responses and susceptibility to extinction," Marine Ecology Progress Series, vol. 337, pp. 1-13, 2007.

[52] M. S. Pratchett, "Changes in coral assemblages during an outbreak of Acanthaster planci at Lizard Island, northern Great Barrier Reef (1995-1999)," Coral Reefs, vol. 29, no. 3, pp. 717-725, 2010.

[53] B. M. Riegl and S. J. Purkis, "Model of coral population response to accelerated bleaching and mass mortality in a changing climate," Ecological Modelling, vol. 220, no. 2, pp. 192-208, 2009.

[54] C. Sheppard, M. Al-Husiani, F. Al-Jamali et al., "The Gulf: a young sea in decline," Marine Pollution Bulletin, vol. 60, no. 1, pp. 13-38, 2010.

[55] M. S. Pratchett, S. K. Wilson, N. A. J. Graham et al., "Coral bleaching and consequences for motile reef organisms: past, present and uncertain future effects," in Coral Bleaching, M. van Oppen and J. Lough, Eds., pp. 139-158, Springer, Heidelberg, Germany, 2009.

[56] D. J. Coker, M. S. Pratchett, and P. L. Munday, "Coral bleaching and habitat degradation increase susceptibility to predation for coral-dwelling fishes," Behavioral Ecology, vol. 20, no. 6, pp. 1204-1210, 2009.

[57] T. P. Hughes, A. H. Baird, E. A. Dinsdale et al., "Detecting regional variation using meta-analysis and large-scale sampling: latitudinal patterns in recruitment," Ecology, vol. 83, no. 2, pp. 436-451, 2002. 
[58] M. Adjeroud, F. Michonneau, P. J. Edmunds et al., "Recurrent disturbances, recovery trajectories, and resilience of coral assemblages on a South Central Pacific reef," Coral Reefs, vol. 28, no. 3, pp. 775-780, 2009.

[59] J. P. Chevalier and D. H. H. Kuhlmann, "Les scléractiniaires de Moorea, île de la Société (Polynésie Française)," Journal de la Société des Océanistes, vol. 77, pp. 55-75, 1983.

[60] C. Bouchon, "Quantitative study of scleractinian coral communities of Tiahura reef," in Proceeding of the 5th International Coral Reef Congress, vol. 6, pp. 279-284, 1985.

[61] L. Penin, M. Adjeroud, M. Schrimm, and H. S. Lenihan, "High spatial variability in coral bleaching around Moorea (French Polynesia): patterns across locations and water depths," Comptes Rendus, vol. 330, no. 2, pp. 171-181, 2007.

[62] M. S. Pratchett, M. Trapon, M. L. Berumen, and K. ChongSeng, "Recent disturbances augment community shifts in coral assemblages in Moorea, French Polynesia," Coral Reefs. In press.

[63] M. Adjeroud, "Factors influencing spatial patterns on coral reefs around Moorea, French Polynesia," Marine Ecology Progress Series, vol. 159, pp. 105-119, 1997.

[64] M. Adjeroud, D. Augustin, R. Galzin, and B. Salvat, "Natural disturbances and interannual variability of coral reef communities on the outer slope of Tiahura (Moorea, French Polynesia): 1991 to 1997," Marine Ecology Progress Series, vol. 237, pp. 121-131, 2002.

[65] D. Augustin, Variabilité à long terme des peuplements du récifs de Tiahura, Moorea, Polynésie Française: 1971-1997, Ph.D. thesis, Ecole Pratique des Hautes Études, Paris, France, 1998.

[66] D. Augustin, R. Galzin, P. Legendre, and E. B. Salvat, "Variation inter-annuelle des peuplements récifaux du récifbarrière de Tiahura (île de Moorea, Polynésie française)," Oceanologica Acta, vol. 20, no. 5, pp. 743-756, 1997.

[67] Y. Bouchon-Navaro and C. Bouchon, "Impact of coral degradation on a chaetodonidae fish assemblage (Moorea, French Polynesia)," in Proceeding of the 5th International Coral Reef Congress, vol. 5, pp. 427-432, Tahiti, French Polynesia, 1985.

[68] J. A. Fagerstrom, "Reef flat community dynamics, Tiahura, Moorea Island French Polynesia: I. Degradation 1971-1987," in Proceeding of the 7th International Coral Reef Congress, vol. 2, pp. 762-768, Tahiti, French Polynesia, 1992.

[69] R. Galzin, J.-P. Marfin, and B. Salvat, "Long term coral reef monitoring programm: heterogeneity of the Tiahura barrier reef (Moorea, French Polynesia)," Galaxea, vol. 11, pp. 73-91, 1993.

[70] B. Salvat, A. Aubanel, M. Adjeroud et al., "Le suivi de l'état des récifs coralliens de Polynésie Française et leur récente évolution," Revue d'Ecologie (La Terre et la Vie), vol. 63, no. 1-2, pp. 145-177, 2008.

[71] T. J. Done, P. K. Dayton, A. E. Dayton, and R. Steger, "Regional and local variability in recovery of shallow coral communities: Moorea, French Polynesia and central Great Barrier Reef," Coral Reefs, vol. 9, no. 4, pp. 183-192, 1991.

[72] M. G. Gleason, "Effects of disturbance on coral communities-bleaching in Moorea, French Polynesia," Coral Reefs, vol. 12, no. 3-4, pp. 193-202, 1993.

[73] I. M. Côté, J. A. Gill, T. A. Gardner, and A. R. Watkinson, "Measuring coral reef decline through meta-analyses," Philosophical Transactions of the Royal Society B, vol. 360, no. 1454, pp. 385-395, 2005.

[74] T. Lison de Loma, Y. Chancerelle, and F. Lerouvreur, "Evaluation des densités d'Acanthaster planci sur l'île de
Moorea," Rapport CRIOBE UMS 2978 CNRS-EPHE RA149, 2006.

[75] P. J. Moran and G. De'ath, "Estimates of the abundance of the crown-of-throns starfish Acanthaster planci in outbreaking and non-outbreaking populations on reefs within the Great Barrier Reef," Marine Biology, vol. 113, no. 3, pp. 509-515, 1992.

[76] P. J. Moran, Crown-of-Thorns Sea Star: Questions and Answers, vol. 35, Australian Institute of Marine Science, Townsville, Australia, 1988.

[77] R. G. Pearson, "Recovery and recolonisation of coral reefs," Marine Ecology Progress Series, vol. 4, pp. 105-122, 1981.

[78] T. J. Done, "Effects of two Acanthaster outbreaks on coral community structure: the meaning of devastation," in Proceedings of the 5th International Coral Reef Symposium, vol. 5, 1985.

[79] R. G. Pearson and R. Endean, "A preliminary study of the coral predator Acanthaster planci (L.) (Asteroidea) on the Great Barrier Reef," Fish Notes, vol. 3, pp. 27-55, 1969.

[80] R. H. Chesher, "Destruction of pacific corals by the sea star Acanthaster planci," Science, vol. 165, no. 3890, pp. 280-283, 1969.

[81] M. S. P. Baine, "A major outbreak of crown-of-thorns starfish in Bootless Bay, Central Province, Papua New Guinea," Coral Reefs, vol. 25, no. 4, p. 607, 2006.

[82] P. J. Moran, R. H. Bradbury, and R. E. Reichelt, "Mesoscale studies of the crown of thorns/coral interaction: a case of history from the Great Barrier Reef," in Proceeding of the 5th International Coral Reef Symposium, vol. 5, 1985.

[83] R. G. Pearson, "Recolonization by hermatypic corals of reefs damages by Acanthaster," in Proceeding of the 2th International Coral Reef Symposium, vol. 2, pp. 207-215, 1974.

[84] M. J. Lourey, D. A. J. Ryan, and I. R. Miller, "Rates of decline and recovery of coral cover on reefs impacted by, recovering from and unaffected by crown-of-thorns starfish Acanthaster planci: a regional perspective of the Great Barrier Reef," Marine Ecology Progress Series, vol. 196, pp. 179-186, 2000.

[85] M. W. Colgan, "Succession and recovery of coral reef after predation by Acanthaster planci (L.)," in Proceeding of the 4th International Coral Reef Symposium, vol. 2, pp. 333-338, 1981.

[86] R. H. Randall, "Coral reef recovery following extensive damage by the "crown of thorns" starfish Acanthaster planci (L.)," Publications of the Seto Marine Biological Laboratory, vol. 20, pp. 469-489, 1973.

[87] J. H. Connell, T. P. Hughes, and C. C. Wallace, "A 30-year study of coral abundance, recruitment, and disturbance at several scales in space and time," Ecological Monographs, vol. 67, no. 4, pp. 461-488, 1997.

[88] B. Salvat, "Blanchissement et mortalité des scléractiniaires sur les récifs de Moorea (archipel de la Société) en 1991," Comptes Rendus de l'Academie des Sciences Paris, vol. 314, no. 3, pp. 105-111, 1992.

[89] S. L. Coles and B. E. Brown, "Coral bleaching-capacity for acclimatization and adaptation," Advances in Marine Biology, vol. 46, pp. 183-223, 2003.

[90] J. A. Maynard, K. R. N. Anthony, P. A. Marshall, and I. Masiri, "Major bleaching events can lead to increased thermal tolerance in corals," Marine Biology, vol. 155, no. 2, pp. 173-182, 2008.

[91] T. J. Done, "Coral community adaptability to environmental change at the scales of regions, reefs and reef zones," American Zoologist, vol. 39, no. 1, pp. 66-79, 1999. 
[92] P. A. Marshall and A. H. Baird, "Bleaching of corals on the Great Barrier Reef: differential susceptibilities among taxa," Coral Reefs, vol. 19, no. 2, pp. 155-163, 2000.

[93] M. S. Pratchett, "Influence of coral symbionts on feeding preferences of crown-of-thorns starfish Acanthaster planci in the western pacific," Marine Ecology Progress Series, vol. 214, pp. 111-119, 2001.

[94] G. De'ath and P. J. Moran, "Factors affecting the behaviour of crown-of-thorns starfish (Acanthaster planci L.) on the Great Barrier Reef: 2: feeding preferences," Journal of Experimental Marine Biology and Ecology, vol. 220, no. 1, pp. 107-126, 1998.

[95] C. R. C. Sheppard, M. Spalding, C. Bradshaw, and S. Wilson, "Erosion vs. recovery of coral reefs after 1998 El Niño: chagos reefs, Indian Ocean," Ambio, vol. 31, no. 1, pp. 40-48, 2002.

[96] M. S. Pratchett, P. L. Munday, S. K. Wilson et al., "Effects of climate-induced coral bleaching on coral-reef fishesecological and economic consequences," Oceanography and Marine Biology, vol. 46, pp. 251-296, 2008.

[97] P. L. Munday, "Habitat loss, resource specialization, and extinction on coral reefs," Global Change Biology, vol. 10, no. 10 , pp. 1642-1647, 2004.

[98] O. Hoegh-Guldberg, S. Andrefoet, K. Fabricius et al., "Coral reef ecosystems," in Vulnerability of Pacific Fisheries to Ongoing Climate Change, J. D. Bell, A. Hobday, and J. Johnson, Eds., chapter 5, SPC, Noumea, New Caledonia.

[99] J. D. Bell, M. Kronen, A. Vunisea et al., "Planning the use of fish for food security in the Pacific," Marine Policy, vol. 33, no. 1, pp. 64-76, 2009.

[100] K. E. Fabricius, K. Okaji, and G. De'ath, "Three lines of evidence to link outbreaks of the crown-of-thorns seastar Acanthaster planci to the release of larval food limitation," Coral Reefs, vol. 29, no. 3, pp. 593-605, 2010.

[101] N. K. Dulvy, R. P. Freckleton, and N. V. C. Polunin, "Coral reef cascades and the indirect effects of predator removal by exploitation," Ecology Letters, vol. 7, no. 5, pp. 410-416, 2004.

[102] H. Sweatman, "No-take reserves protect coral reefs from predatory starfish," Current Biology, vol. 18, no. 14, pp. 598599, 2008. 

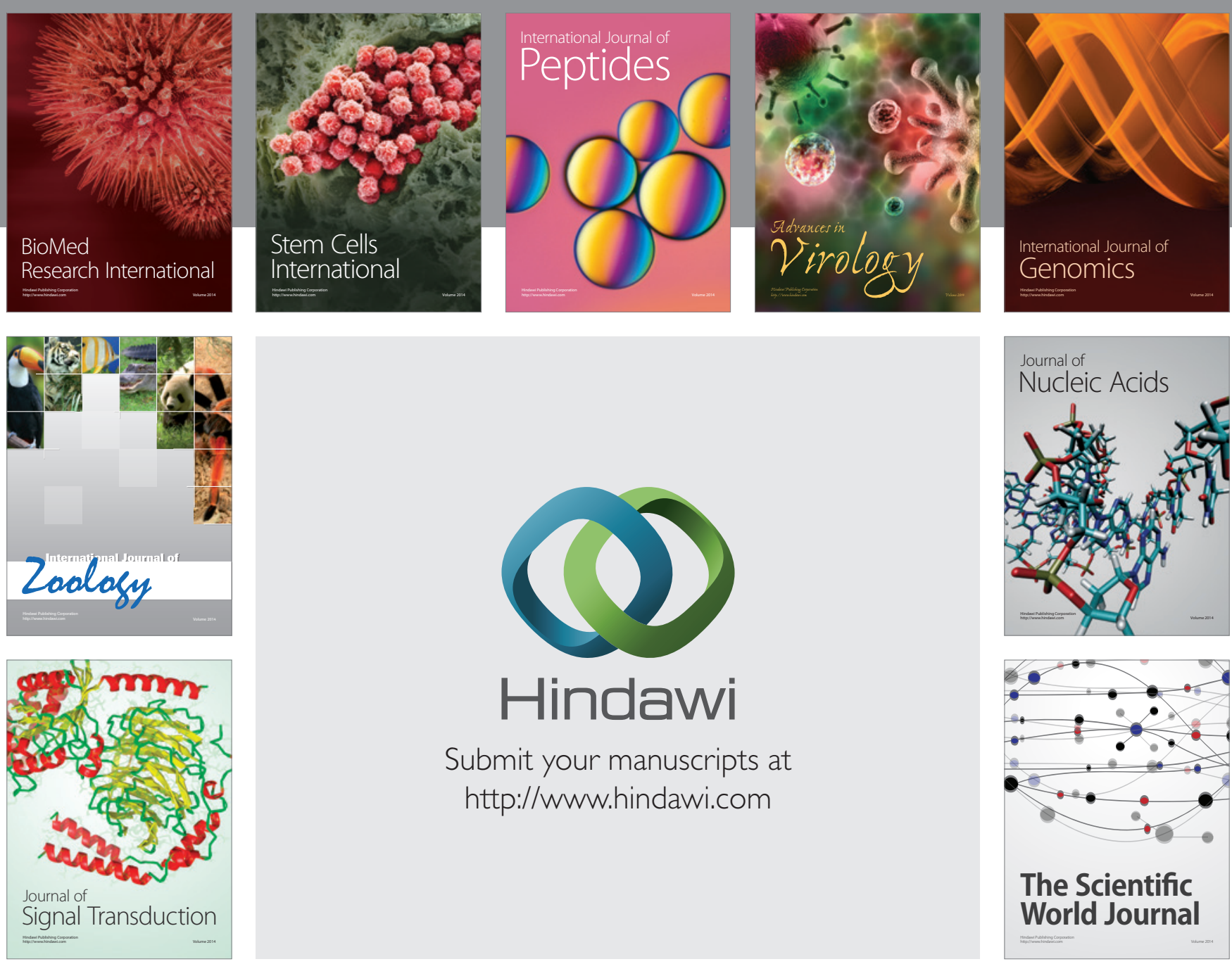

Submit your manuscripts at

http://www.hindawi.com
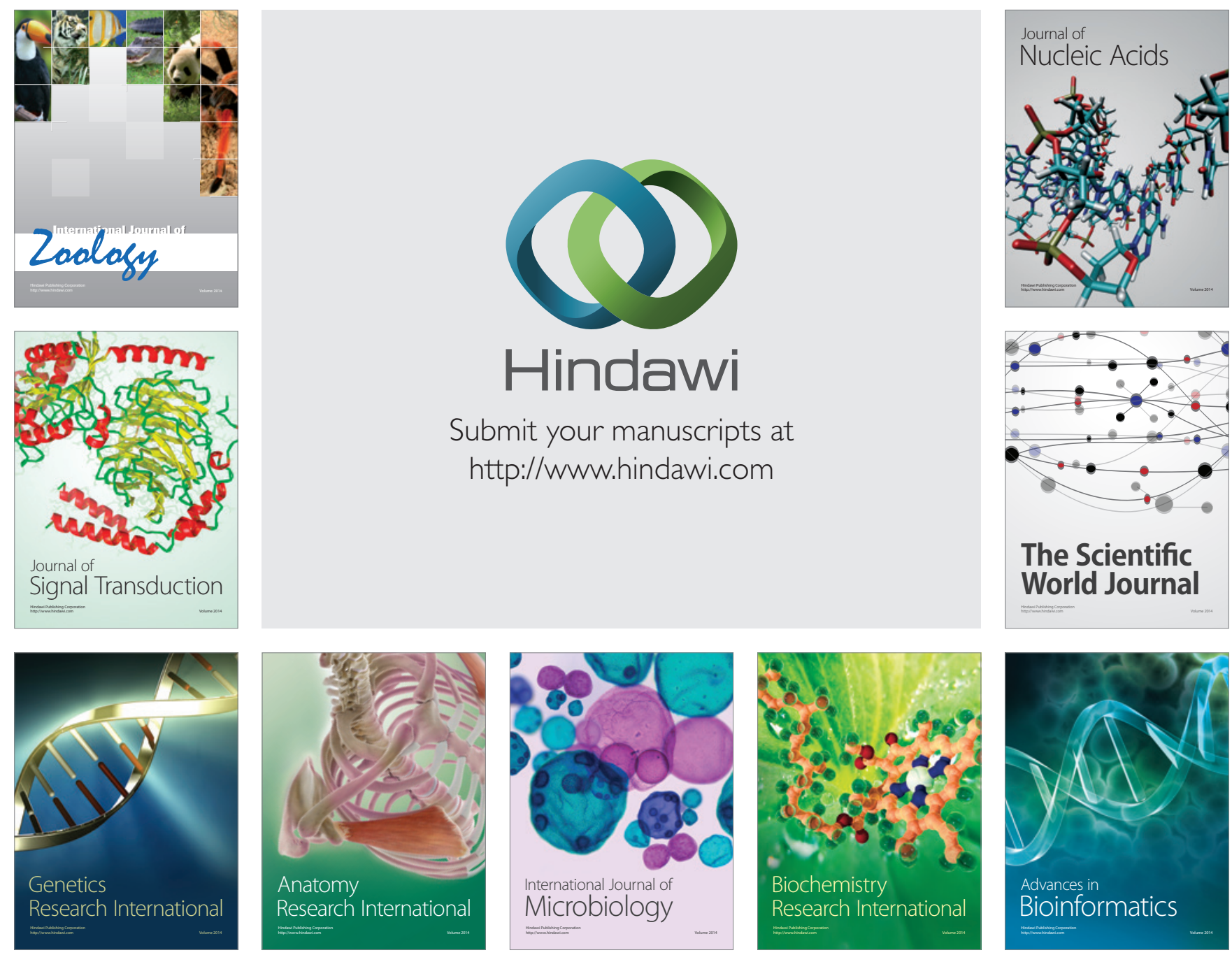

The Scientific World Journal
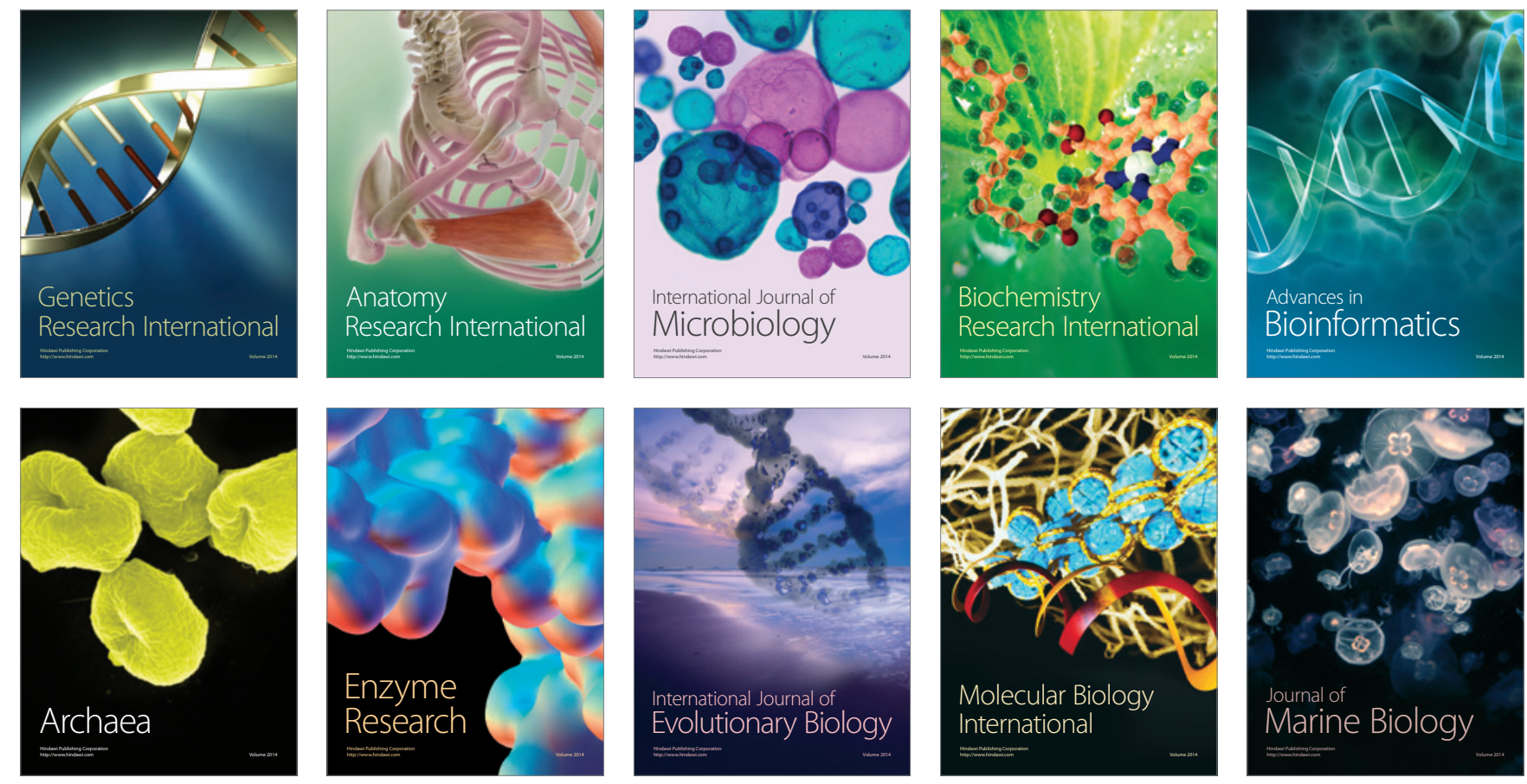